\title{
STRATEGIC PLANNING IN CORRELATION WITH INTERNAL AUDIT
}

\author{
Jelena Bošnjak \\ City Administration of Zrenjanin, Zrenjanin, Serbia
}

\begin{abstract}
Strategic planning and Internal audit are important for organizational existence in dynamic business world. Strategic planning, by definition sets up guidelines for organizations actions in achieving goals, while internal audit is designed to help organization to reach these goals. Research for this paper is based on theoretical considerations and surveys done in different types of organizations by overseeing the connection and correlation between strategic planning and Internal audit. Research showed that strategic planning is very demanding function in organization and requires many different resources in order to create sustainable strategy for the organizations future. Internal audit in organization is a function that adds value, by ensuring the management that system of controls in organization is functioning well, and the risks are put to minimum. This paper is a shorted version of authors Master thesis - Strategic Planning in Organization Aided by Internal Audit.
\end{abstract}

Key words: internal audit, strategic management, strategic planning, strategic thinking.

\section{THREE TYPES OF STRATEGIC ACTIVITY}

Three types of strategic activity are: strategic thinking, strategic planning and strategic management.

\subsection{Strategic thinking}

Strategic thinking defines well the creation of the vision in organization, which includes the process of defining and achieving objectives of organization in a difficult environment in which there is considerable uncertainty about the future. Strategic thinking is about reconsidering that future, sometimes in a small way. Strategic thinking usually may be as far as any strategist wishes to go, in manner of providing the rational framework, which clarifies how all current operations are to be organized (White, 2004, p 61).

Vision - a Vision is the "big picture" created with the passion that helps employees feel what they are supposed to be doing in the organization (Hitt, Ireland, \& Hoskisson, 2009, p. 18). The vision of an organization defines what that organization is. It is at the core of the organization's identity, representing the reason why organization exists. It is closely linked with what the organization can do, reflecting its resources, capabilities and competencies. The vision precedes, but overlaps strategy. It is basically the creative or artistic part of strategy. The existence of a clear vision is a prerequisite for the formulation of a good strategy (White, 2004, p. 55).

Mission - a Mission specifies the business in which the organization intends to compete and the customers it intends to serve, according to Ireland and Hitt (1992). The organization mission is more solid than its vision. As well as the vision, a mission should establish an organization's uniqueness and should be inspirational and relevant to all stakeholders, according to Duncan (1999). Vision and mission together deliver the foundation of the organization's needs to choose and implement one or more strategies.

The possibility of creating an effective mission rises when employees have a strong sense of the ethical standards that should direct their performances as they work in order to help the organization accomplish its vision. Therefore, business ethics are a vital part of the organization's discussions upon decisions what it wants to become as well as who it anticipates to serve and how it wishes

Corresponding author. Email: jelena.bosnjak@grad.zrenjanin.rs

ISSN 2560-4961 (online)

(C) 2019 IPMA Serbia

doi: 10.18485/epmj.2019.9.2.4 
to serve those individuals or groups (Ward, Lankau, Amason, Sonnenfeld, \& Agle, 2007).

Objectives and Goals - all organizations have objectives and goals. Objectives are organizations performance targets - the results and outcomes it wants to achieve. Organizational structure and activities are designed and resources are allocated around the objectives to enable their achievement.

Organization interpret their vision and mission into objectives. The goals are more specific and they translate the objectives to short term perspective, they provide meaning and sense of direction to organizational effort. Goals also act as benchmarks for guiding organizational activity and for evaluating how the organization is performing. Objectives with strategic focus relate to outcomes that strengthen an organizations overall business position and competitive strength. (Hitt, et al., 2009, p. 19).

\subsection{Strategic planning}

\section{"Plans are of little importance, but planning is essential."}

Winston Churchill, former British Prime Minister

Strategic planning undertakes a further step in the defining of the future in which strategic actions are created into formal and articulate written plans and action to achieve those plans Any plan enforces the human will upon an environment which is full of unexpected changes (White, 2004, p 61).

Planning is a crucial management activity no matter what type of organization is being managed (Certo \& Certo, 2012, p. 160). The essential purpose of planning is to help the organization reach its objectives (Certo, \& Certo, 2012, p. 161).

Mintzberg (1994) finds a variety of reasons for planning. He states that organizations must create plan in order to coordinate its activities. According to him, organizations must plan to make sure that the future is seriously considered, organizations must plan to be "rational", and finally, organizations must plan to control.
Strategic plan should be simple, clear and written.

According to Mintzberg (1994), the three assumptions underlying strategic planning are:

* assumptions of formalization where the strategy making process can be programmed by the use of systems;

* assumptions of objectivity in which "thought must be detached from action, strategy from operations, perceived thinkers from real ones, and "strategists" from the objects of their strategies";

* assumptions of quantification where "the strategy making process is determined by 'hard data' including detailed 'facts' about the organization and its surroundings."

Strategic planning is involving the use of formal planning methods, including the development of explicit plans with a full range of objectives, and its application to all business units and functional areas within the organization, and at all levels. All parts of the organization have a carefully defined role to play in the realization of such a plan.

\subsection{Strategic management}

Strategic management is strategic thinking applied to action. Strategic management allows an organization to coordinate all its functional activities in accomplishment of clear objectives. It is about the reshaping of some part of the future. In a world of constant change this reshaping is a requirement for the long-term success of one organization (White, 2004, p 61).

According to Wheelen and Hunger (2012) strategic management is set of managerial decisions and actions that governs the long run performance of an organization. It includes environmental scanning, strategy formulation, strategy implementation, and finally evaluation and control.

According to David (2011), strategic management can be defined as the discipline of formulating, applying, and assessing cross-functional decisions that allow an organization to accomplish its objectives. According to this definition, strategic management focuses on assimilating all 
functions in organization, such as management, marketing, finance, operations, research and development, and information systems to achieve organizational success. The purpose of strategic management is to exploit and create new and different opportunities for future of organization (David, 2011, p. 6).

Strategic management is what managers do to develop the organization's strategies. It's an important duty that involves all primary management functions in organization, such as planning, organizing, leading, and controlling (Robbins, \& Coulter, 2012, p. 225).

\subsubsection{Strategic management process}

Many authors agreed that the strategic management process in terms of strategic planning is consisted of three phases - first phase - strategy formulation, which includes phases of development of vision, mission and statement, performance of external and internal audit and selection of strategy. Second phase is implementation of strategy, and final phase in monitoring and evaluation of strategy.

The strategic management process is the complete set of obligations, decisions, and actions required for an organization to achieve strategic competitiveness and to earn above average returns. (Hitt, et al., 2009, p. 6).

According to Mahoney and McGahan (2007), organization first step in the process should be to analyze its external and internal environments to determine its resources, capabilities, and core competencies.

After analysis of this information, the organization develops its vision and mission and formulates its strategy. To implement strategy, the organization takes actions toward achieving strategic competitiveness. Effective strategic actions that take place in the perspective of cautiously combined strategy formulation and implementation result in desired strategic outcomes. It is a dynamic process and very demanding (Hitt, et al., 2009, p. 6).
Other activity that has to be performed is internal examination of existed resources. That is how the resource-based model was introduced. Resources based model assumes that each organization is a collection of unique resources and capabilities. The exclusivity of its resources and capabilities is the basis for an organization's strategy and its ability to earn above-average returns (Acedo, Barroso, \& Galan, 2006)

According to the resource-based model, differences in organization's performances across time are due to their exceptional resources and capabilities rather than to the industry's structural characteristics. This model also assumes that organization obtain different resources and develop exclusive capabilities based on how they combine and use the resources (Newbert, 2007).

Through continued use, competences become stronger and more difficult for competitors to understand and imitate. According to Schoemaker and Amit (1994) as a source of competitive advantage, a capability "should be neither so simple that it is highly imitable, nor so complex that it defies internal steering and control."

\section{PERFORMING INTERNAL AUDIT IN PROCES OF STRATEGIC PLANNING "Weak leadership can wreck the soundest strategy."-Sun Tzu}

According to David (2011), the process of performing an internal audit matches the process of performing an external audit in organization. Representative managers and employees from the organization should be involved in shaping an organization's strengths and weaknesses.

The process of performing an internal audit makes available more opportunity for contributors to understand how their jobs, departments, and divisions fit into the entire organization. Advantage of this process is great, since managers and employees perform better when they understand how their work affects different areas and actions of the organization. Another aspect of performing internal audit is that it is an excellent opportunity for improving the process of communication in the organization, since in 
order to understand the functions of the organization, representatives of every department communicate among themselves and most importantly, strengths and weaknesses can be determined collectively (David, 2011, p. 93).

Communication is the most important word in management during the process of performing internal audit in process of strategic planning.

In process of performing an internal strategic management audit, managers from different departments of the organization are able to understand the nature and effect of decisions in other business areas in their organization. Knowledge of these relationships is very important in process of creating objectives and strategies (David, \& David, 2017, p. 180).

Performing an internal audit in organization in process of strategic planning, requires gathering, assimilating, and evaluating information about the organization's operations. In this stage, important success factors, that are consisted of both strengths and weaknesses, should be identified and prioritized.

A failure to identify and comprehend relationships among the functional areas of business of one organization can be harmful to strategic management and strategic planning process.

Ansoff (1987) explained well the process of strategic planning in organization in relation of including every business area in process. $\mathrm{He}$ stated that during the first fifty years, successful organizations focused their energies on optimizing the performance of one of the principal functions such as production or operations, research and development, or marketing. Nowadays, due to the growing complexity and dynamic environment, success more and more depends on a sensible combination of several functional influences. This switch from a single function focus to a multifunction focus is essential for successful strategic management and strategic planning.

\section{INTERNAL AUDIT - FUNCTION IN ORGANIZATION}

Internal audit is the profession-occupation that emerged in mid- $20^{\text {th }}$ century. Internal auditors are individuals that are certified for matter of performing internal audits in organization. Internal audit profession has its standards, procedures and guidelines that follows and that internal auditors work by.

Internal audit could be organized as an independent unit within the organization, or organization could have internal auditor as individuals. Either way, it depends on management requirements.

Internal auditors are right hand of a decision makers in one organization. They assure managers that system of internal controls in organization is functioning well and that risks of unwilling events are put to minimum.

Internal auditors are well experienced and independent individuals with great knowledge of organization that they work in, since they have availability of processes and people in organization by obtaining their regular audit job.

Evolution of internal audit profession was for sure pushed by constant changes in business world. Another feature of evolution of internal audit lays within the management in organization. Management understood that every aspect that could help in achieving organization goals is necessary and mandatory in turbulent business world. Internal audit function for sure is essential for one organization and for management.

Through the years, internal audit function went from being a monitoring - passive function in organization, up to becoming a consultant, very dynamic function in organization.

\subsection{Basic roll and evolution of Internal Audit function / profession}

The basic role of internal audit function is to provide assurance that management has implemented a suitable internal control system to prevent risk in organization. 
Another roll of internal audit function is to help management achieve company's goals.

As well as providing assurance in functioning of system of controls in organization, internal auditing should provide internal consulting services to all levels of the organization in terms of training, assistance, guidance and counsels, and in that way it helps organization in achieving its goals.

Goodwin (2004) states that the new definition of internal audit function has moved its focus from internal audit function to a function of adding value to the organization by improving the operations of the organization and by evaluating and improving the effectiveness of the organization's risk management, control and governance processes.

At it's very beginning, in its pioneer phase, internal audit has been seen as a monitoring function, the "organizational policeman and watchdog" (Morgan, 1979), and it was tolerated as a necessary component of organizational control, but believed to be a passive to the accomplishment of major corporate objectives.

Internal audit function became major managerial control device trough measuring and evaluating the effectiveness of organizational controls, according to Carmichael, Willingham and Schaller (1996). That as well is related to the organizational structure and rules of business (Cai, 1997).

Internal audit function is defined as well by COSO (Committee of Sponsoring Organizations of the Treadway Commission, 1992) as a technique which brings essential security to the organization regarding the integrity of financial matters.

Definition of internal audit function, that was issued by the IIA in June 1999, evidently states that "the internal auditing activity should evaluate and contribute to the improvement of risk management, control and governance" (IIA, 1999).

This new definition moves the focus of the internal audit function from a function of assurance to value added function. By defining it as such, it shifted profession of internal audit function toward a standards-driven approach with a sensitive identity (Bou-Raad, 2000; Krogstad, Ridley, \& Rittenberg, 1999).

Reding, et al. (2013) give internal audit function connection to the organization's goals. Internal audit function is intended to help the organization to reach its objectives. Fulfillment of organizational objectives defines the organization's accomplished success.

Organization's objectives and goals are what the company wants to achieve. If goals are clear and can be measured, they are estimate criteria of the organization's success (Reding et al., 2013).

COSO (Committee of Sponsoring Organizations of the Tredway Commission) categorizes organization's objectives as follows (Reding et al., 2013):

* Strategic objectives are what management do and plan to do in order to create value for the organization

* Operations objectives focus on organization's operations in order to increase effectiveness and efficiency

* Reporting objectives are about reporting internal and external information and the level of its reliability

* Compliance objectives concentrate on existing laws and regulations and their implementation in the organization

According to Pickett (2005, p. 8), internal auditors are able to assist top management with the following:

* Monitoring activities that management cannot monitor itself

* Identifying opportunities and minimizing risks of failure

* Validating reports to management

* Protecting management in technical analysis that is beyond their knowledge

* Providing information for the decision-making process

* Reviewing for the future as well as for the past

* Helping managers manage by pointing to violation of procedures and management principles. 
Internal audit function has undergone dramatic changes and has expended its scope in order to make greater support to the organization goals. Internal audit function is as well performing its role in diverse cultural and legal environments within different organizations; which varies in size, structure, purpose and also in persons (Saud, 2015).

Achieving objectives and managing valuable organizational resources requires systems, processes and people. Internal auditors work closely with managers to review operations then report their findings. The internal auditor must be well experienced in the strategic objectives of their organization and the industry where organization is operating in order that they have a clear understanding of how the operations of any given part of the organization fit into the bigger picture.

As an independently organized unit, with authority and expertise it poses, internal audit function is useful and important tool for management so management is able to observe inner strengths of organization in order to use them in best way for achieving organization's goals and objectives and creating sustainable strategy for future of the organization.

\section{RESEARCH ANALYSIS}

As it was discussed in previous parts, strategic planning is very demanding and complex process in organization. It is one of the major rolls of top management in organization.

In order to create sustainable strategy for future, management needs to involve all relevant factors in organization.

During the process strategic planning, in previous parts of the paper were identified steps in process of strategic planning and resources that management has available for such operation.

It is evident that managers do perform internal audit in process of strategic planning as a part of process.

What could as well adds value and what could give more assurance and insights to the process of strategic planning in organization is to involve internal auditor during this process.

In this part of paper will be presented research results based on the indication that internal audit function could be significant in the process of strategic planning in organization.

This part of paper presents the data collected through two surveys - questionnaires.

First questionnaire was imposed to internal auditors in public and private sector and financial institutions in Serbia with idea and tendency to understand their opinion about their involvement into process of strategic planning in organization.

Second survey was imposed to decision makers in different organizations in Serbia in order to overlook their view of a roll of internal auditor in process of strategic planning in organization.

\subsection{Internal Auditors Survey}

First survey was prepared for Internal auditors with intention to understand what perception of strategic planning in organization internal auditors have.

Assumption is that the more experienced internal auditors would be more aware that their roll is necessary in process of strategic planning in organization. Experienced internal auditor have more knowledge about organization that they work in and do the auditing of system of controls. Internal auditors should be aware of potential risks and obstacles that organization could face.

Survey was conducted of twenty-six questions Fifty-eight internal auditors responded on survey.

First set of question was general characteristics of participants, gender, age and education.

Thirty-eight percent of examined internal auditor are male, and sixty-two percent are female with average year of 41 . This data shows that internal audit occupation is attractive for mid age workers, and that female are more involved in internal audit 
occupation than male, based on this collected sample. This part of questions is conducted to see statistically ratio on percentage of male and female internal auditors as well as average age. This processed data is not further relevant for paper investigation.

Sixty percent of examined participants completed bachelor studies, thirty-six completed as well master studies. Majority $(84,5 \%)$ of examined completed economic bachelor studies. Average years of working experience among participants is 16 years, and as an Internal auditor, average year of working is 5 . This statistic show that internal audit profession is relatively new in Serbia.

In order to understand whether the participants are certified internal auditors, sixty percent answered that they have some sort of certification, opposite of frothy percent being non certified.

Out of 58 participants, twenty-one are certified as an Internal auditor for public sector (OIRJS), four of them are certified for international auditor certificate (CIA), four of them are certified with chamber of auditors (KOR) in Serbia. One has both CIA and KOR certification, two have KOR and OIRJS certification, and twenty-six are not certified yet.

Sixty-four percent of participants are from public sector, and most of them are working in local self-government. Out of 37 respondents from public sector, 17 are from local self-government, 12 are from state owned public company, and rest are from state government or other state owned institutions. Out of thirty-six percent that are in private sector, sixty-seven percent are within financial institutions. That is 21 respondents is from private sector, where 14 of them are from financial institutions, and 5 of them work in foreign owned organization, and two in domestic company.

Forty-one percent performed more than 45 internal audits in their career, seventeen percent performed between 15 and 25 audits, and 33 percent provided less than fifteen audits. Which shows that almost half of participants have been experienced in their work.
Within last employer, majority of $39 \%$ (23 of them) performed less than 15 audits, 19 of them performed more than 45 audits, and 11 of them performed between 15-25 audits. This data showed that internal auditors do go for a job change among companies, but still large number of participants are well experienced in new organization, where 30 of them performed more than 15 audits within last employer.

Within last employer, most of the participants performed majority of internal audits - system audits, which means that internal auditors have overlook on particular systems in organization. More audits of systems that auditors perform, better understanding on organizations processes they have.

Important for internal auditors is for sure relation with managers/decision makers, since the management sets the tone in organization.

If management is fully aware of roll of internal auditors - that internal auditors are support system, consultants and in alignment with management in achieving goals of organization, then internal auditor's job in organization is reassured.

Forty out of fifty-eight participants answered that they have very good relation with decision makers in organization, which is $69 \%$ of examined. $22,4 \%$ answered that they have good relation with managers, and $8,6 \%$ answered that they have not so good relation with decision makers. This sample show that very high percent of participants have support form decision makers in completing their job as internal auditors.

Important relation as well is with the coworkers form other departments in organization. Since auditors need to process information, observe systems in organization, they have to communicate with workers responsible for certain systems in organization. Direct, open and trustworthy relation among internal auditors and coworkers from other department assures better understanding of potential risks in organization and brings organization closely in achieving its goals.

Sixty-five percent of internal auditors responded that their relation with coworkers is 
very good, thirty-two percent assert good relation, and only $1,7 \%$ declare that they have poor relation.

Observing answers on relation of internal auditors with management and coworkers from another departments, it is showed that internal auditors do have support from both management and coworkers, whether they do feel slightly more comfortable in relation with coworkers from another departments.

Which leads us to next set of questions that are related with cooperation between internal auditors and decision makers when it comes to decision making in organization.

As it was stated above, roll of internal audit evolved during last seventy years, especially in last twenty years, where roll of internal audit is aligned with adding value to organization, by performing different duties.

According to Pickett, (2005) emerging roll of internal auditors is providing information for the decision-making process, which in some level involves internal auditor in process of decision making.

Internal auditors were asked whether they were involved in process of decision making in organization, for financial decision, operational decision, strategic decision, or if they were not at all involved in process of decision making.

Sixty-nine percent answered that they were not involved at all in any decision making process, $12 \%$ answered that they were involved in strategic decision, and $12 \%$ were involved in operational decisions. Only six percent were involved in financial decisions.

Analysis based on this answers clearly shows that roll of internal auditors in process of decision making is not recognized by managers/decision makers in organization.

Following question was intended to more closely examine reason of involvement of internal auditors in process of decision making in organization, by asking them were they willingly offered their expertise to the decision makers in process of decision making for financial, operational and strategic decisions. $67 \%$ answered that they never offered their knowledge and skills to the decision makers in process of decision making that are important for organization.

This implies that there is still to be working in relation decision makers-auditors when it comes to emerging roll of internal auditors in providing information for the decision-making process, which in some level involves internal auditor in process of decision making.

Next set of question was imposed to understand whether internal auditors are aware of strategic planning in organization and their roll in whole process.

Internal auditors were asked if their organization has Strategic document. 86\% answered that organization possess Strategic document.

When internal auditors were asked if they were involved in process of strategic planning, $77,6 \%$ answered no.

Same percentage of participants $(77,6 \%)$ answered that they have good knowledge of organization and working experience in order to participate in process of strategic planning in organization, but when they were asked would they participate in process of strategic planning in organization on request of decision makers, only 55\% answered that they would accept to be involved in that process.

This states that internal auditors do feel like they understand organization they work in, that auditors feel strongly that they have enough working experience, but at the other hand not as high percent of auditors is eager to be involved in process of strategic planning.

14 out of 58 internal auditors did perform audit of strategic document.

In order to understand better how internal auditors see their roll in strategic planning, following questions were asked:

Based on their experience, is it important that internal auditor is involved in process of strategic planning? 
$58,6 \%$ percent answered yes, 27,6\% answered no, and $13,8 \%$ were not opinionated on this topic.

This shows that internal auditor feel that roll of internal audit is important in process of strategic planning in organization.

Last question was to define where internal auditors see their roll most valuable in process of strategic planning, where $54 \%$ answered in process of implementation and monitoring strategic planning. 29\% answered in audit of process of strategic planning. $7 \%$ answered that their roll is best seen in process of audit of strategic plan. 3\% answered that they do not recognize roll of internal audit in process of strategic planning, and $7 \%$ answered that strategic planning is not internal audit roll at all.

According to this sample and answers from internal auditors, it could be stated that internal auditors do feel strongly and self-confident when it comes to understand the organization they work in.

Internal auditors do see their roll in process of strategic planning as well as they would prefer to be involved in process of strategic planning. Most valuable roll of internal audit in process of strategic planning, according to their answer would be in process of auditing implementation and monitoring of strategic planning.

\subsection{Decision makers Survey}

This Survey is conducted with intention to oversee if decision makers fully understand the roll of internal auditors in organization. Survey is conducted of twenty-five questions, and prepared in that way to oversee at decision makers previous experience in decision making, length of work in current organization and attitude towards internal audit and finally their opinion on position of internal audit in process of strategic planning in organization.

Among decision makers, 73,3\% are male, opposite to $26,7 \%$ of female. Forty-seven percent of them are over 40 years old.
Sixty percent have bachelor degree, and 20 percent have master and $\mathrm{PhD}$ level of study completed.

Five of them have more than 25 years of working experience. Other examined have more than 10 years of working experience.

As decision makers, most of them $(33,3 \%)$ have less than five years of experience and only one examined have more than 25 years of working experience. Fifty-three percent of examined have between five and fifteen years of experience as decision makers.

Most of them (60\%) are less than five years' decision makers in organization that they currently work.

In all but one organizations, internal audit unit is established less than 5 years ago. Only one organization have more than fifteen Internal auditors and one has between 3 and 10 auditors, other organization have between one and three internal auditors.

Most of the decision makers $(66,7 \%)$ answered that they have good insight of internal auditor job in their organization. Very good insight of internal auditor job has $26,7 \%$ of examined. One examined answer that has poor understanding of internal auditor job in organization.

Seventy-three percent of examined answered that in their organization, Internal auditors perform audits of financial processes in organization.

All but one decision maker answered that their collaboration with internal auditors is good. Same answers were regarding the collaboration that internal auditors have with other coworkers in organization.

$86,7 \%$ of decision makers have insights on skills and knowledge that internal auditors have.

All of the decision makers answered that they use recommendation and reports that internal auditors conduct as a part of their job. 
Only three participants never included Internal auditor in process of decision making in organization.

According to the decision makers, internal auditors are proactive as well, all but one internal auditors offered their skills to managers in process of decision making.

In process of strategic planning in organization, all decision makers used help of internal auditors $-13,3 \%$ directly involved internal auditor in process of planning, and $86,7 \%$ used reports and recommendations of internal auditors in process of strategic planning in organization.

According to decision makers opinion, most valuable roll of internal auditors in process of strategic planning would be in audit of implementation and monitoring of strategy. (40\% of decision makers answered as this). $26,4 \%$ of examined answered that most significant role of internal auditor would be in auditing of process of strategic planning. $13,3 \%$ managers answered that they do not recognize roll of internal auditors in process of strategic planning, and the same percentage of examined answered that strategic planning is not a roll of internal auditors.

According to this sample and answers from decision makers in organization, it could be stated that managers do recognize significance of internal audit in their organization. They use skills and knowledge of internal auditor in process of decision making, as well as they use reports and recommendation that internal auditors conduct in process of auditing systems of control in organization. Most valuable roll of internal audit in process of strategic planning, according to their answer would be in process of auditing implementation and monitoring of strategic planning.

\section{CONCLUSION}

All functions are necessary in process of strategic planning in organization, also, all functions in organization are essential for creation of good and sustainable strategy.

Decision makers need to be aware of potential that lays within the organization and they 44 have to be able to embrace all functions within the organizational order not to miss any important aspect in preparation of sustainable strategy.

Strategic planning evolved significantly during past fifty years. Decision makers are more prepared to use every possible tool that exist in order to create sustainable strategy for their organization.

Internal audit function as well grew during last fifty years. It came a long way from a passive function in organization, to very dynamic one.

Internal audit has significant insight of systems and controls in organization. As such function in organization, it should have notable position in process of strategic planning, and decision makers should have reliable source of information to use in process of strategic planning throughout personal involvement and throughout reports and recommendation internal auditors prepare as their job.

Roll of internal audit in the process of strategic planning is significant, useful and valuable for the organization.

\section{REFERENCES}

Acedo, F. J., Barroso, C., \& Galan, J. L. (2006). The resource-based theory: Dissemination and main trends, Strategic Management Journal, 27: 621-636.

Ansoff, I. (1987). Strategic Management of Technology. Journal of Business Strategy. 7(3) (Winter 1987): 38

Bou-Raad, G. (2000). Internal Auditors and a Value-added Approach: The New Business Regime. Managerial Auditing Journal, 15(4), pp. 182-186.

Cai, C. (1997). On the Functions and Objectives of Internal Audit and their Underlying conditions. Managerial Auditing Journal, 12(4), pp. 247-250.

Carmichael, D. R., Willingham, J. J., \& Schaller, C. A. (1996). Auditing Concepts and Methods. A Guide to Current Theory and Practice. McGraw-Hill. 
Certo, S. C., \& Certo, T. S. (2012). Modern management: concepts and skills. New Jersey: Prentice hall.

Committee of Sponsoring Organizations of the Tredway Commission (COSO) (1992). Internal Control-integrated Framework. Coopers and Lybrand, pp. 1-4.

David, F. R. (2011). Strategic management: concepts and cases. New Jersey: Prentice hall.

David, F., \& David, F. (2017). Strategic Management: A Competitive Advantage Approach, Concepts and Cases. England: Pearson Education

Duncan, W. J. (1999). Management: Ideas and Actions, New York: Oxford University Press, 122-125.

Goodwin, J. (2004). A Comparison of Internal Audit in the Private and Public Sectors. Managerial Auditing Journal. 19(5), pp. 640-650.

Hitt, M. A., Ireland, R. D., \& Hoskisson, R. E. (2009). Strategic Management: Competitiveness and Globalization (Concepts and Cases). USA: South-Western Cengage Learning

Ireland, R. D., \& Hitt, M. A. (1992). Mission statements: Importance, challenge, and recommendations for development. Business Horizons, 35(3): 34-42.

The Institute of Internal Auditors (1999). Definition of Internal Auditing. The Institute of Internal Auditors. Altamonte Springs, FL

Krogstad, J., Ridley, A., \& Rittenberg, L. (1999). Where we're Going? Internal Auditor, 12, pp. 27-33.

Mahoney, J. T., \& McGahan, A. M. (2007). The field of strategic management within the evolving science of strategic organization. Strategic Organization. 5: 79-99;
Mintzberg, H. (1994). The Rise and Fall of Strategic Planning. Free Press. New York

Morgan, G. (1979). Internal audit role conflict: a pluralist view, Managerial Finance, 5(2), pp.160-170.

Newbert, S. L. (2007). Empirical research on the resource-based view of the firm: An assessment and suggestions for future research. Strategic Management Journal, 28: 121-146;

Pickett, K. (2005). The essential handbook of internal auditing. Chichester: John Wiley \& Sons. pp. 8, 335, 337

Reding, K., Sobel, P., Anderson, U., Head, M., Ramamoorti, S., Salamasick, M., \& Riddle, C. (2013). Internal auditing. Altomonte Springs, Fla.: Institute of Internal Auditors, Research Foundation.

Robbins, S. P., \& Coulter, M. (2012). Management. New Jersey: Prentice hall.

Schoemaker, P. J. H., \& Amit, R. (1994). Investment in strategic assets: Industry and firm-level perspectives, in P. Shrivastava, A. Huff, \& J. Dutton (eds.), Advances in Strategic Management, Greenwich, CT: JAI Press, 9.

Saud, S. (2015). The Role of Internal Audit in Organization Goals Achievements: A Security of Exchange Commission of Pakistan (SECP) Perspective. Research Journal of Finance and Accounting Vol.6, No.24

Ward, A. J., Lankau, M. J., Amason, A. C., Sonnenfeld, J. A., \& Agle, B. A. (2007). Improving the performance of top management teams. MIT Sloan Management Review, 48(3): 85-90

White, C. (2004). Strategic Management. New York: Palgrave Macmillan

Wheelen, T. L., \& Hunger, J. D. (2012). Strategic management and business policy: toward global sustainability. New Jersey: Pearson Education 